\title{
Pathology of finfish and mud crabs Scylla serrata during a mortality event associated with a harbour development project in Port Curtis, Australia
}

\author{
M. M. Dennis ${ }^{1,2}$, B. K. Diggles ${ }^{3}$, R. Faulder ${ }^{4}$, L. Olyott ${ }^{5}$, S. B. Pyecroft ${ }^{6}$, \\ G. E. Gilbert ${ }^{7,8}$, M. Landos ${ }^{9, *}$ \\ ${ }^{1}$ QML Vetnostics, Murarrie, QLD 4172, Australia \\ ${ }^{2}$ Ross University School of Veterinary Medicine, Basseterre, St Kitts, West Indies \\ ${ }^{3}$ DigsFish Services Pty Ltd, Bribie Island, QLD 4507, Australia \\ ${ }^{4}$ University of Newcastle, Central Coast Campus, Ourimbah, NSW 2258, Australia \\ ${ }^{5}$ Len Olyott Consulting, Bellbowrie, QLD 4070, Australia \\ ${ }^{6}$ University of Adelaide, School of Animal \& Veterinary Sciences, Roseworthy Campus, SA 5173, Australia \\ ${ }^{7}$ DeVry Medical International's Institute for Research and Clinical Strategy, 485 US Highway 1 South, Building B, \\ Floor 4, Iselin, NJ 08830, USA \\ ${ }^{8}$ Center for Teaching and Learning, Ross University School of Medicine, PO Box 266, Roseau 00152, \\ Commonwealth of Dominica, West Indies \\ ${ }^{9}$ Future Fisheries Veterinary Service Pty Ltd, East Ballina, NSW 2478, Australia
}

\begin{abstract}
The objective of this study was to assess the extent and describe the nature of a multispecies marine finfish and crustacean disease event that occurred in Gladstone Harbour, Australia, 2011-2012. Finfish were examined for this study in January to April 2012 from sites where diseased animals were previously observed by the public. Gross abnormalities, including excessive skin and gill mucus, erythema, heavy ecto-parasitism, cutaneous ulceration, corneal opacity, and exophthalmos, were higher $(25.5 \%)$ in finfish from Gladstone Harbour $(\mathrm{n}=435)$ than in those from an undeveloped reference site, $250 \mathrm{~km}$ to the north $(5.5 \%, \mathrm{n}=146, \mathrm{p}<0.0001)$. Microscopic abnormalities, especially non-infectious erosive to ulcerative dermatitis and internal parasitism, were more prevalent in fish from Gladstone Harbour $(n=34$ of 36 , prevalence $=94.4 \%)$ than in fish from the reference site $(3$ of 23 , prevalence $=13.0 \% p<0.0001$ ). The prevalence of shell lesions was higher in mud crabs Scylla serrata sampled from Gladstone Harbour (270 of 718, prevalence = $37.5 \%$ ) than from the reference site ( 21 of 153 , prevalence $=13.7 \%$; $<0.0001$ ). The significantly higher prevalence of ulcerative skin disease and parasitism in a range of species suggests affected animals were subjected to influences in Gladstone Harbour that were not present in the control sites. The disease epidemic coincided temporally and spatially with water quality changes caused by a harbour development project. The unique hydrology, geology, and industrial history of the harbour, the scope of the development of the project, and the failure of a bund wall built to retain dredge spoil sediment were important factors contributing to this epidemic.
\end{abstract}

KEY WORDS: Dredging $\cdot$ Gladstone $\cdot$ Disease $\cdot$ Teleosts $\cdot$ Elasmobranchs $\cdot$ Crustaceans

\section{INTRODUCTION}

The Great Barrier Reef (GBR) is the planet's largest coral reef and one of its most complex ecosystems and richest sites of biodiversity. In recognition of its universally outstanding values, it was established by UNESCO in near entirety as a World Heritage Area in 1981.

*Corresponding author: matty.landos@gmail.com
Port Curtis (Port of Gladstone) $\left(23^{\circ} 47.9^{\prime} \mathrm{S}, 151^{\circ}\right.$ $\left.15.4^{\prime} \mathrm{E}\right)$ existed prior to its inclusion into the Great Barrier Reef World Heritage Area. It is a rapidly growing industrialized harbour, one of the world's largest coal export ports, and host to a wide range of other industries. Accumulation of heavy metals (including copper, arsenic, nickel, and chromium, aluminium, manganese, and zinc), polycyclic aromatic

(C) The authors 2016. Open Access under Creative Commons by Attribution Licence. Use, distribution and reproduction are unrestricted. Authors and original publication must be credited. 
hydrocarbons, and tri-butyl tin have been observed in the aquatic environment and biota of Gladstone Harbour, and these are thought to reflect a combination of the harbour's heavy industry history, urban development, and local geology (Apte et al. 2005, Jones et al. 2005, Andersen et al. 2006, VicenteBeckett et al. 2006, Angel et al. 2010).

In 2010, the largest dredging operation in Australian history, the Western Basin Dredging and Disposal Project (WBDDP) and associated harbour development plans, was approved for the Port of Gladstone in order to extend and deepen shipping channels and establish berths for the Liquefied Natural Gas export industry on Curtis Island and Wiggins Island coal dock, adjacent to Gladstone Harbour. By the end of 2013, over 23 million cubic meters of seabed had been dredged from the harbour (Commonwealth of Australia 2013). Shortly after the harbour development project works commenced, an unusual and prolonged large-scale aquatic animal disease event occurred in Gladstone Harbour. Disease and mortality were observed in a wide range of aquatic species, including teleosts, elasmobranchs, crustaceans, mollusks, chelonians, cetaceans, and sirenia. Community concern regarding the diseased aquatic animals prompted investigation by the Queensland government and resulted in a temporary closure of the commercial fishery in September 2011. Subsequently, the Queensland Government formed a scientific panel (Gladstone Fish Health Scientific Advisory Panel 2012), and further studies by the Queensland Government followed in response to recommendations of their report (Department of Agriculture, Fisheries and Forestry 2013).

In January to April 2012, in response to continuing public reports of diseased aquatic animals being observed in Gladstone Harbour, a privately funded independent veterinary diagnostic investigation was undertaken. The aim of this study was to describe the nature of diseases present in marine finfish and mud crabs Scylla serrata from Gladstone Harbour and to identify the likely cause(s).

\section{MATERIALS AND METHODS}

\section{Collection of case history}

Reports of diseased aquatic animals were recorded for the period from February 2011 through to October 2012 from a number of sources. Realtime reporting was facilitated by close engagement with the commercial fishing industry operating within the harbour. Fishermen were encouraged wherever possible to document abnormalities with photographs. Further reports of diseased aquatic animals were collected from interviews with Gladstone Area Water Board management and hatchery staff, local newspapers, and recreational fishermen and from the websites of Gladstone Ports Corporation, Queensland Fisheries, and Department of Environment and Resource Management. The details of reports are included in Table S1 in the Supplement at www.int-res.com/articles/suppl/d121p173_ supp.pdf.

\section{Sampling}

Two main areas were sampled: Gladstone Harbour and Stanage Bay (Thirsty Sound, $250 \mathrm{~km}$ north of Gladstone Harbour). Sample sites within Gladstone Harbour reflected regions that were both accessible to commercial fishing operations and representative of the spatial extent of the fish health problems reported around Gladstone Harbour. Sampling of various species of teleost and elasmobranch finfish and mud crabs Scylla serrata from Gladstone Harbour took place in January and February 2012 (Fig. 1, Table 1). All animals were sampled live during routine commercial fishing operations. Fish were collected using gill nets or cast nets. Crabs were collected using commercial crab pots.

Mud crabs and finfish were sampled from the reference site at Stanage Bay in April 2012 (Table 1) as part of routine commercial fishing operations using gill nets. Crabs were collected using commercial crab pots. This site had experienced significant freshwater influx in December 2010 to April 2011 at the same time as the Gladstone region, and there were no active harbour development activities within the site.

\section{External examination}

Soon after being removed from nets or pots, all animals were examined by a veterinarian and/or fish parasitologist for the presence or absence of external lesions such as ulcers, erythema, and features of gill injury. Fish were restrained manually and grossly examined, as soon as they were lifted into the boat, and removed from the fishing gear. Fish were classified as having ecto-parasitism if parasites were found associated with the skin or gill surfaces. Parasite 


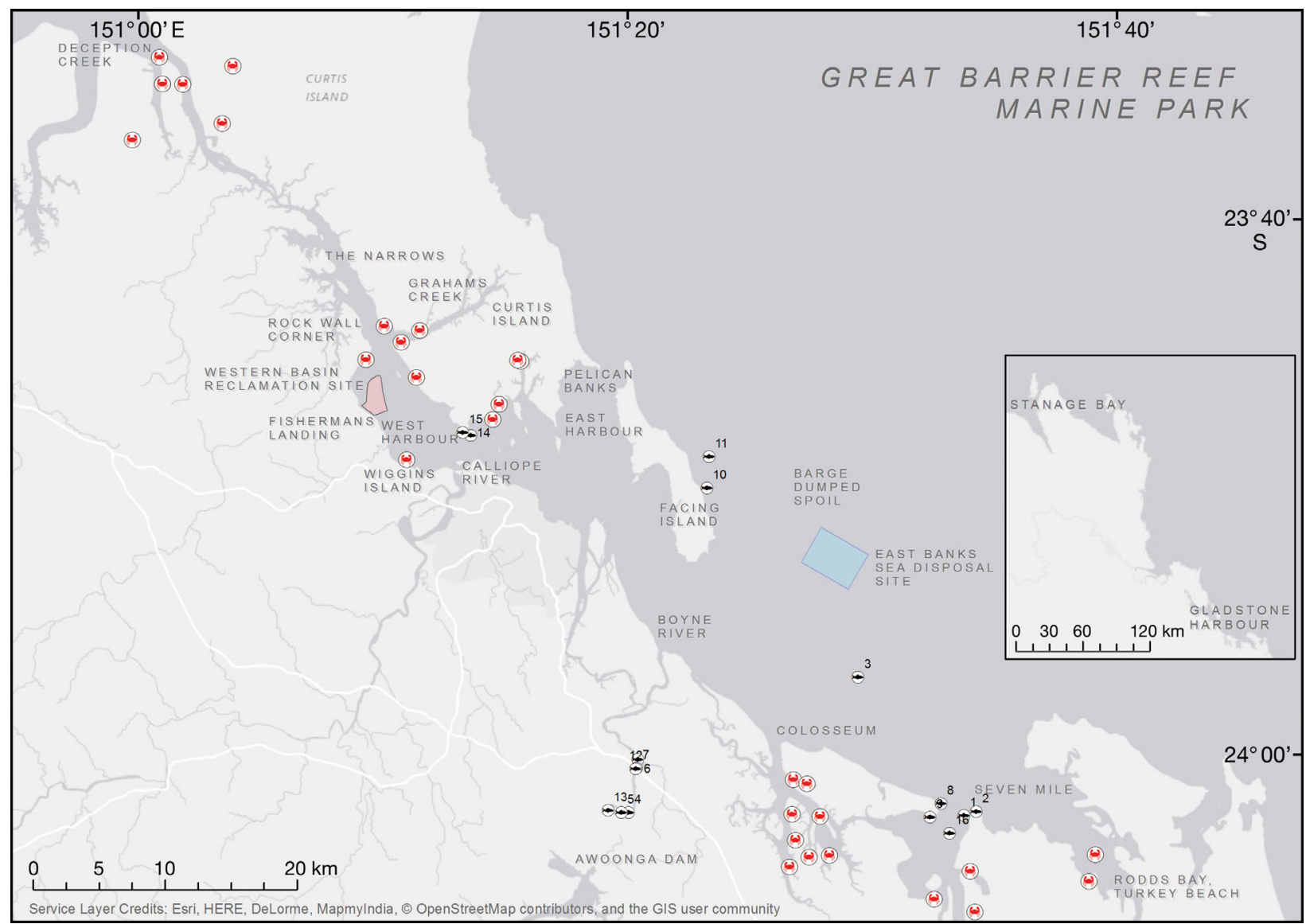

Fig. 1. Location of finfish and mud crab Scylla serrata sampling sites within the study area. The failed bund wall is indicated by the border of the pink-shaded reclamation area

Table 1. Summary of finfish examined. 'Other': species for which $<10$ individuals were sampled included batfish Platax spp., black jewfish Protonibea diacanthus, blubber lip bream Plectorhinchus gibbosus, blue salmon Eleutheronema tetradactylum, dart Trachinotus coppingeri, estuary cod Epinephelus coioides, giant herring Elops hawaiiensis, giant trevally Caranx ignoblis, king salmon Polydactylus macrochir, oyster cracker Trachinotus blochii, shortbeak gar Arrhamphus spp., sicklefish Drepane spp., silver biddy Gerres spp., slatey bream Diagramma pictum, spotted scat Scatophagus argus, stripey snapper Lutjanus carponotatus, and yellowfin bream Acanthopagrus australis

\begin{tabular}{|c|c|c|c|c|c|c|c|c|c|c|c|c|c|c|c|c|c|c|}
\hline \multirow{2}{*}{ Species examined } & \multicolumn{17}{|c|}{ Gladstone Harbour sampling site(s) (see Fig. 1) } & \multirow{2}{*}{$\begin{array}{l}\text { Stanage } \\
\text { Bay }\end{array}$} \\
\hline & 1 & 2 & 3 & 4 & 5 & 6 & 7 & 8 & 9 & 10 & 11 & 12 & 13 & 14 & 15 & 16 & All & \\
\hline Barramundi Lates calcarifer & 1 & 1 & & 10 & 8 & 1 & 14 & & & & & 1 & 1 & 2 & 1 & 4 & 44 & 79 \\
\hline Catfish Arius spp. & & & & & 2 & & & & & & & & & & & 2 & 4 & 22 \\
\hline Mullet Mugil spp. & & & & 32 & 7 & & & 150 & & & & & & & & & 189 & 5 \\
\hline $\begin{array}{l}\text { Queenfish Scomberoides } \\
\text { commersonianus }\end{array}$ & & & 27 & & & & & 2 & & 6 & & & & & & & 35 & 1 \\
\hline Rays (F. Dasyatidae, Rajidae) & 1 & 3 & & & & & & 1 & & 2 & & & & & & 3 & 10 & 1 \\
\hline $\begin{array}{l}\text { Requiem sharks } \\
\text { (Family Carcharhinidae) }\end{array}$ & 1 & 7 & 1 & 1 & 4 & & & & & 4 & 20 & & & & & 4 & 41 & 5 \\
\hline $\begin{array}{l}\text { Other sharks (F. Sphyrnidae, } \\
\text { Triakidae, Scyliorhinidae) }\end{array}$ & & 4 & 2 & & & & & & & & 3 & & & & & 1 & 10 & - \\
\hline $\begin{array}{l}\text { Threadfin salmon Polydactylus } \\
\text { multiradiatus }\end{array}$ & & & & & & & & & & & & & & & & & 0 & 12 \\
\hline Whiting Sillago spp. & & 1 & & 2 & 4 & & & 45 & & & & & & & & & 52 & - \\
\hline Other & & 8 & & 8 & 11 & & 1 & 2 & 8 & 3 & 2 & & & & & 6 & 50 & 21 \\
\hline Total examined & 3 & 24 & 30 & 53 & 36 & 1 & 15 & 200 & 8 & 15 & 25 & 1 & 1 & 2 & 1 & 20 & 435 & 146 \\
\hline
\end{tabular}


identifications were undertaken immediately onboard the sample vessel.

For crabs, the surfaces of the carapace were cleaned of algae and sediment with a brush or towel to ensure all gross cutaneous lesions could be visualized.

\section{Necropsy}

Necropsy was conducted on board fishing vessels. Animals exhibiting gross tissue abnormalities were necropsied when observed. Where no grossly abnormal animals were observed (particularly at the reference sites), sampling for histology took place on a convenience basis. Finfish were euthanized by a percussive blow to the head, or via a spike through the brain (iki-jime), before samples of gill, brain, heart, kidney, spleen, skin, liver, gonad, and intestine were excised for histology. Samples of carapace, gill, and hepatopancreas, and grossly abnormal organs were collected from crabs after ablation of the ganglia.

\section{Histology}

Whole finfish or finfish tissues were immersed in $10 \%$ neutral buffered formalin immediately after sampling. Tissues were a maximal thickness of $<1.5 \mathrm{~cm}$. Mud crab tissues were preserved in Davidson's fixative for $24 \mathrm{~h}$ before being transferred to $95 \%$ ethanol. Tissues were fixed for at least $48 \mathrm{~h}$ prior to transporting to the laboratory for routine processing for histopathology using standard methods. Tissues containing bony elements, such as skin, gill, or crab carapace, were decalcified by immersing in $5 \%$ nitric acid for $30 \mathrm{~min}$ prior to processing. Sections were embedded in wax, cut at $5 \mu \mathrm{m}$, and stained with hematoxylin and eosin (H\&E). Additional histochemical stains, such as Brown and Brenn gram, Giemsa, periodic acid-Schiff, Ziehl-Neelsen acid fast, and Grocott's methenamine silver stains were also applied to sections where pathological findings indicated use.

\section{Bacteriology}

Bacterial isolation was attempted from 20 finfish exhibiting skin lesions that were taken from the Boyne river (Fig. 1, Sites 4 to 7) in January 2012. A variety of fish species were sampled, including barramundi Lates calcarifer $(\mathrm{n}=13)$, requiem sharks
(Family Carcharhinidae) $(\mathrm{n}=5)$, and catfish Arius spp. $(\mathrm{n}=2)$. A total of 24 swabs were taken from kidney ( $\mathrm{n}=14)$, liver $(\mathrm{n}=8)$, and peritoneal fluid $(\mathrm{n}=2)$. Swabs were streaked onto $5 \%$ sheep blood agar and thiosulfate-citrate-bile salts-sucrose agar and incubated at $25^{\circ} \mathrm{C}$ for 48 to $72 \mathrm{~h}$. No growth was evident on any plates after $48 \mathrm{~h}$, after which all plates were transferred to a commercial veterinary diagnostic laboratory for further incubation and assessment. Any significant isolates grown were identified using standard microbiological methods for aquatic organisms (Whitman 2004) and MicroSys ${ }^{\circledR}$ V36 (DPIPWE, Launceston, Tasmania) identification kits.

\section{Mud crab shell disease scoring and sampling}

Shell lesions were graded according to the methods and scoring system developed by Andersen et al. (2000), as follows: Grade 1 - non-perforated <5 mm diameter discoloration of shell ('rust spot'); Grade 2 non-perforated $>5 \mathrm{~mm}$ diameter discoloration of shell ('rust spot'); Grade 3 - partial or full-thickness shell perforation < 5 mm diameter; Grade 4 - partial or full-thickness shell perforation of 5 to $20 \mathrm{~mm}$ diameter; Grade 5 - partial or full-thickness shell perforation $>20 \mathrm{~mm}$ diameter.

Sampling locations for mud crabs, represented sites where active commercial crabbing was taking place (Fig. 1). Mud crabs from Deception Creek, The Narrows, West Harbour, Graham's Creek, and East Harbour regions were classified as 'Inner Harbour'. Colosseum and 7 Mile crabbing locations were classified as 'Outer Harbour', and those from Rodd's Bay and Turkey Beach regions were classified as 'Out of Harbour Reference', similar to regions used by others for monitoring habitat (Davies et al. 2012). The Out of Harbour Reference sites were thought to be those within the Gladstone region least likely to be impacted by the port development activity (Davies et al. 2012), as they are located well outside the port limits and furthest from dredging and disposal activities. For comparative purposes, mud crabs were also collected from the reference site at Stanage Bay, $250 \mathrm{~km}$ to the north.

\section{Statistical analysis}

Descriptive statistics including prevalences and 95\% confidence intervals were calculated using $\mathrm{R}$ software (R Core Team 2014). 
Finfish

A Wilcoxon rank sum test was used to compare prevalences of external disease, gross cutaneous abnormalities, and ecto-parasitism among finfish of the study population and finfish of the reference site. A Pearson's chi-squared test was used to compare prevalences of gross cutaneous abnormalities and ecto-parasitism among species groups (species groups categorized as per Table 1).

\section{Mud crabs}

A relative risk estimate (and 95\% confidence interval) was calculated to estimate the risk of gross shell lesions for mud crabs from the study area. A Pearson's chi-squared test was used to compare prevalences of gross shell lesions among crabs of the study population to those of the reference site as well as among crabs of the Inner Harbour, Outer Harbour, and Out of Harbour reference sites. A Mann-Whitney $U$ test was used to compare shell lesion scores be- tween crabs from Gladstone Harbour and those from the Out of Harbour reference sites.

\section{RESULTS}

\section{Description of the epidemic}

Key events during the disease epidemic are summarized in Fig. 2. The index aquatic animal disease event occurred on 9 February 2011, when a localized fish kill involving undescribed numbers and species of aquatic organisms was reported near the Gladstone Marina by a local newspaper. This disease event occurred approximately 4 mo after preparatory dredging activities had begun and 2 mo after construction had begun on an $8 \mathrm{~km}$ long bund wall for the reclamation area (Vision Environment 2011a). The index disease event occurred approximately $8 \mathrm{wk}$ after the onset of a period of unusually high rainfall, which resulted in the overtopping of Awoonga Dam spillway (dam height averaging $1 \mathrm{~m}$ above spillway for around $4-5 \mathrm{wk}$ and peaking briefly at $4 \mathrm{~m}$ around

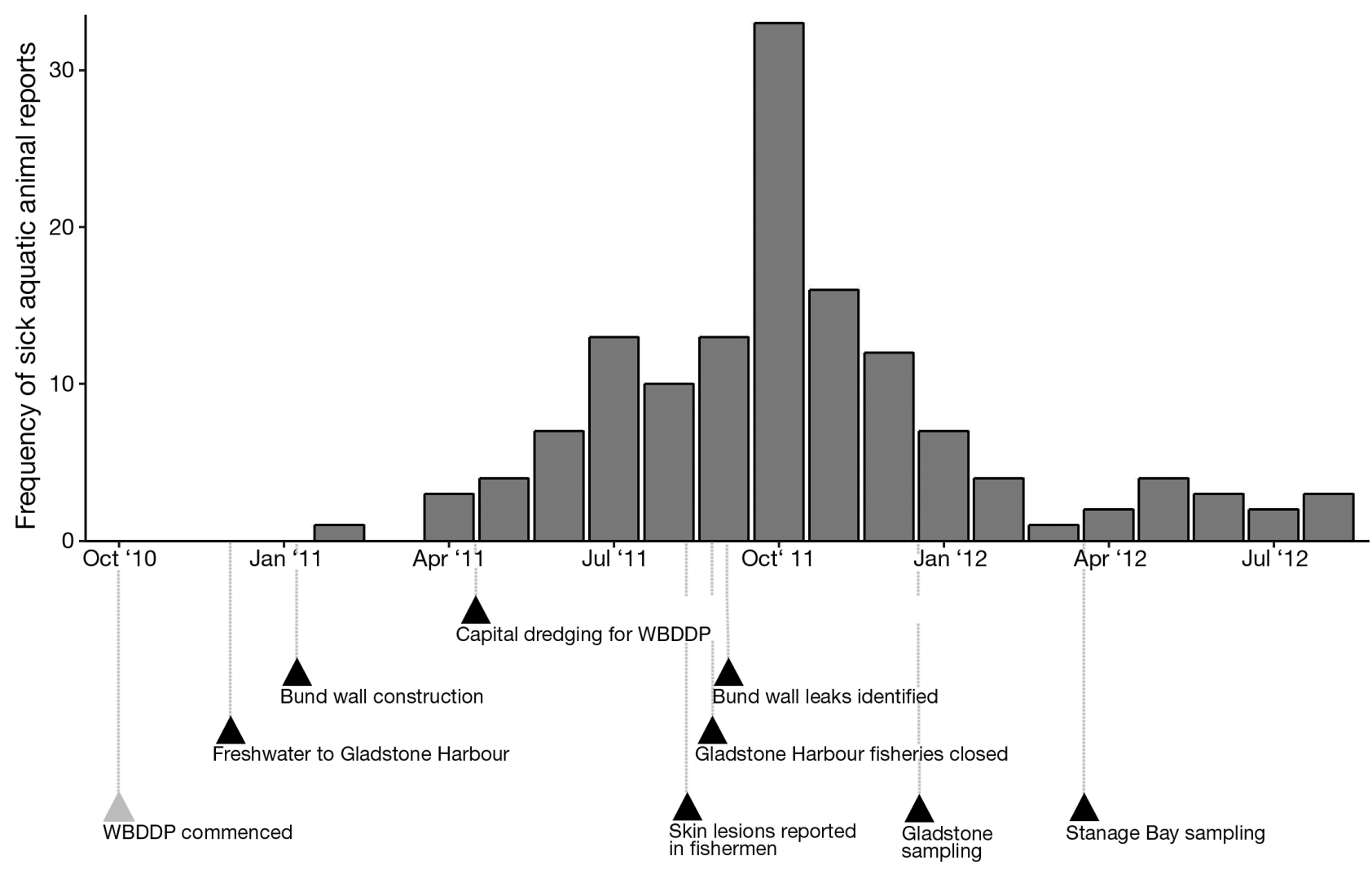

Fig. 2. Frequency of sick aquatic animal reports in Gladstone Harbour (as per Table S1 in the Supplement at www.int-res.com/ articles/suppl/d121p173_supp.pdf) and timeline of key events leading up to and during the multispecies aquatic animal disease epidemic in Gladstone Harbour 2010 to 2012 
the end of December 2010) and large volumes of freshwater movement into Gladstone Harbour. The dam had been stocked from 1996 with hatchery reared barramundi Lates calcarifer, mullet Mugil cephalus, and mangrove jack Lutjanus argentimaculeatus, and the overtopping event, the first in $14 \mathrm{yr}$, permitted the release of an estimated 30000 catadromous barramundi $L$. calcarifer and numerous other smaller resident species (e.g. mullet, catfish Neoarius spp., and bony bream Nematalosa erebi) into the Boyne River, which flows into Gladstone Harbour (Department of Agriculture, Fisheries and Forestry 2013). The elevated freshwater inflows ceased in June 2011, and May to October 2011 had belowaverage rainfall (Australian Bureau of Meteorology 2014). By 31 March 2011, the western basin salinity in Gladstone Harbour had risen to $>26.6$ ppt with outer harbour salinity at $31 \mathrm{ppt}$ (Vision Environment 2011b).

Immediately following these events and continuing until December 2012 (April 2011 to December 2012), numerous diseased aquatic animals were observed and reported appearing over a wide area within the harbour by commercial and recreational fishermen, other members of the community, and Government Fisheries and Environment staff. Harbour development activities continued unabated during this time (Fig. 2). Abnormalities observed included dead fish floating on the water surface or live fish observed or caught with excessive mucus on the skin and gills, skin erythema, heavy external parasitic infestations, and skin ulceration. Less frequently, fish were reported with corneal opacity or reddening, or exophthalmos. Mud crabs Scylla serrata were reported by commercial and recreational fishermen to have increased prevalence of 'rust spots' affecting the carapace. Fishermen and members of the public also reported what were described as 'sick and dying' turtles at multiple time-points and locations, as well as dead dugongs and dolphins. Rates of deaths of dolphins, dugongs, and turtles in 2011 around Gladstone were well above long-term averages (Department of Environment and Heritage Protection 2011a,b,c).

The frequency and number of reports of fish disease around Gladstone continued to escalate to a peak in October 2011 (Fig. 2; Table S1 in the Supplement), coinciding with increasing dredging effort and the initial deposition of cutter-suction dredge spoil in the reclamation area behind the newly completed bund wall (BMT-WBM 2011a). During late September and October 2011, commercial fishermen operating in Gladstone Harbour reported having entire catches rejected by fish wholesalers due to grossly visible skin lesions. At the same time, there were also cases of cutaneous lesions (infected injuries, boils, limb swelling, or rashes), 'flu-like' illness, difficulty breathing, and eye lesions in $>40$ humans, all of whom had contact with the harbour water or fresh seafood product from the harbour immediately prior to the onset of symptoms (Jeremijenko \& Landos 2014). In response to the human health concerns, the Queensland government closed Gladstone Harbour and the surrounding area to commercial and recreational fishing on 16 September 2011 (Gladstone Fish Health Scientific Advisory Panel 2012). Also during this time, chlorophyll a concentrations increased in the Western Basin and The Narrows (Vision Environment 2012a), and dissolved oxygen levels had decreased (Vision Environment 2011c,d,e), together suggestive of algal blooms. Three types of algae that have previously been associated with fish kills, including the diatom Chaetoceros, the cyanobacterial species Trichodesmium erythraeum, and the raphidophyte Chattonella, were identified through water quality compliance monitoring (Vision Environment 2012a). Around the peak of the disease event in late September 2011, salinity was 34 to 36 ppt across Gladstone Harbour (Department of Environment and Resource Management 2011).

\section{Grossly visible lesions in finfish}

The present study examined a total of 581 finfish from 25 species caught in gill nets, including 435 finfish sampled from Gladstone Harbour during January and February 2012 and 146 finfish sampled from the reference site at Stanage Bay in April 2012 (Table 1, Fig. 1). Prevalence of external disease, as indicated by gross external lesions or ecto-parasitism, was significantly higher amongst fish sampled from Gladstone Harbour $(\mathrm{n}=435$, prevalence $25.5 \%, 95 \%$ CI: 21.4 to $29.6 \%$ ) compared to fish from the reference site $(\mathrm{n}=146$, prevalence $5.5 \%, 95 \%$ CI: 1.8 to $9.2 \% ; \mathrm{p}<0.0001)$.

Cutaneous lesions were the predominant type of grossly visible external lesion, including regions of hyperpigmentation, depigmentation, erosion, erythema, ulceration, and/or hemorrhage (Table 2, Fig. 3a-e). The prevalence of gross cutaneous lesions was significantly more common among fish sampled in Gladstone Harbour (prevalence 19.5\%, 95\% CI: 13.1 to $25.9 \%$ ) relative to fish from the reference site (prevalence $0.7 \%, 95 \%$ CI: 0 to $1.5 \%$; p < 0.0001 ). Prevalence of cutaneous lesions was also signifi- 
Table 2. Summary of pathological findings in finfish. See Table 1 for species binomials/families, and a full list of species grouped as 'Other'. Ecto-parasitism is defined by the presence of external parasites infecting the integument and/or gills. Gross skin lesions include regions of hyperpigmentation, depigmentation, erosion, erythema, ulceration, and hemorrhage

\begin{tabular}{|c|c|c|c|c|c|c|}
\hline Species & $\begin{array}{c}\mathrm{N} \\
\text { examined }\end{array}$ & $\begin{array}{c}\text { N gross } \\
\text { ocular } \\
\text { lesions (\%) }\end{array}$ & $\begin{array}{l}\text { N ecto- } \\
\text { parasitism } \\
(\%)\end{array}$ & $\begin{array}{c}\text { N gross } \\
\text { skin lesions } \\
(\%)\end{array}$ & $\begin{array}{c}\text { N examined } \\
\text { by } \\
\text { histology }\end{array}$ & $\begin{array}{c}\text { N significant } \\
\text { histological } \\
\text { lesions }\end{array}$ \\
\hline \multicolumn{7}{|l|}{ Gladstone Harbour } \\
\hline Mullet & 189 & $0(0)$ & $0(0)$ & $5(2.6)$ & 4 & 4 \\
\hline Whiting & 52 & $0(0)$ & $0(0)$ & $1(1.9)$ & 1 & 0 \\
\hline Barramundi & 44 & $5(11.3)$ & $16(36.4)$ & $18(40.9)$ & 9 & 9 \\
\hline Requiem sharks & 41 & $0(0)$ & $9(22.0)$ & $27(65.8)$ & 6 & 5 \\
\hline Queenfish & 35 & $0(0)$ & $28(80.0)$ & $20(62.5)$ & 7 & 7 \\
\hline Other & 50 & $2(4.0)$ & $4(11.8)$ & $7(14.0)$ & 5 & 5 \\
\hline Other sharks & 10 & $0(0)$ & $5(50.0)$ & $5(50.0)$ & 1 & 1 \\
\hline Rays & 10 & $0(0)$ & $1(10.0)$ & $1(10.0)$ & 1 & 1 \\
\hline Catfish & 4 & $1(25.0)$ & $2(50.0)$ & $1(25.0)$ & 2 & 2 \\
\hline Total & 435 & $8(1.8)$ & $56(12.8)$ & $85(19.5)$ & 36 & 34 \\
\hline \multicolumn{7}{|l|}{ Stanage Bay } \\
\hline Barramundi & 79 & $0(0)$ & $0(0)$ & $0(0)$ & 6 & 1 \\
\hline Other & 21 & $0(0)$ & $0(0)$ & $0(0)$ & 1 & 0 \\
\hline Catfish & 22 & $0(0)$ & $2(9.1)$ & $0(0)$ & 3 & 0 \\
\hline Requiem sharks & 5 & $0(0)$ & $5(100)$ & $0(0)$ & 5 & 1 \\
\hline Threadfin salmon & 12 & & & & 1 & 0 \\
\hline Mullet Mugil spp. & 5 & $0(0)$ & $0(0)$ & $1(20.0)$ & 5 & 1 \\
\hline Queenfish & 1 & $0(0)$ & $0(0)$ & $0(0)$ & 1 & 0 \\
\hline Rays & 1 & $0(0)$ & $0(0)$ & $0(0)$ & 1 & 0 \\
\hline Total & 146 & $0(0)$ & $7(4.8)$ & $1(0.7)$ & 23 & 3 \\
\hline
\end{tabular}

cantly different among species groups ( $\mathrm{p}<0.0001)$, ranging from 1.9 to $65.8 \%$ and being most commonly observed in requiem sharks (Family Carcharhinidae), barramundi L. calcarifer, and queenfish Scomberoides commersonianus.

Ecto-parasitism was significantly more common among fish sampled in Gladstone Harbour (prevalence $15.2 \%$, 95\% CI: 11.7 to $18.6 \%$ ) relative to fish from the Stanage Bay reference site (prevalence $4.8 \%, 95 \%$ CI: 1.3 to $8.3 \%$; $p<0.01$ ). The prevalence also differed significantly between species groups ( $\mathrm{p}<0.0001$ ), ranging from 0 to $77.8 \%$ and being most commonly observed in sharks, barramundi, and queenfish. In total, 35 of 86 (40.7\%) of fish with gross cutaneous abnormalities had ecto-parasites, and the association between gross cutaneous abnormalities and ecto-parasitism was significant ( $p<0.0001)$. The monogenean Dermophthirius sp. and copepods Pandarus spp. commonly infested sharks (Fig. 3d), and sea lice Lepeophtheirus spinifer commonly infested queenfish (Fig. 3e). A subsample of queenfish $(\mathrm{n}=27$ ) from near the spoil disposal ground in outer Gladstone Harbour was examined by a fish parasitologist (B. K. Diggles), who found $100 \%$ prevalence of infection with $L$. spinifer at a mean infection intensity of 21.2 parasites per fish (range 4 to 46 ). All queenfish infected with $>10$ L. spinifer had grossly visible cutaneous lesions (Fig. 3e).

Gross ocular lesions were observed only in fish sampled from Gladstone Harbour (prevalence 1.8\%, $95 \% \mathrm{CI}: 0.6$ to $3.0 \%$ ) and in most cases were observed in barramundi but were also observed in 1 each of catfish Arius spp., blubberlip bream Plectorhinchus gibbosus, and black jewfish Protonibea diacanthus. These lesions were often bilateral and included exophthalmos, corneal opacity, corneal ulceration, corneal rupture, phthisis bulbi, hemorrhage into the anterior chamber, conjunctival swelling, and/or scleral injection (Fig. 3f).

\section{Microscopic lesions in finfish}

Significant histopathological abnormalities were observed at high prevalence in fish sampled from Gladstone Harbour (34 of 36, prevalence = 94.4\%) but were uncommon in fish sampled from the reference site ( 3 of 23, prevalence $=13.0 \%$; $p<0.0001$ ) (Table 2).

Inflammatory disease associated with significant parasitism was the most common abnormality observed in 27 of 36 (prevalence $=75.0 \%$ ) fish sampled 

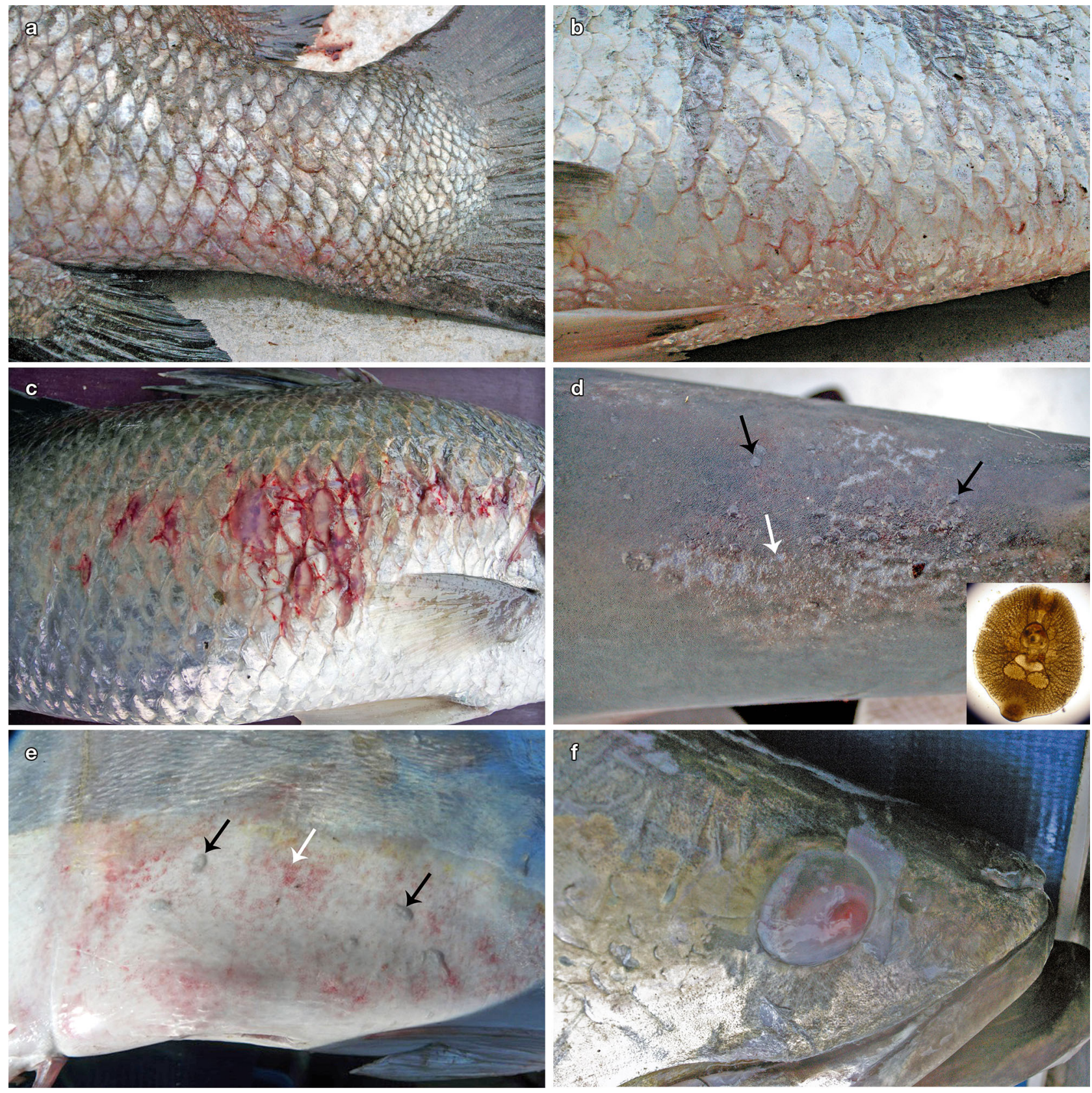

Fig. 3. Photographs of animals caught in (b,e) January or (a,c,d,f) February 2012. (a) Blubberlip bream Plectorhinchus gibbosus caught east of the Facing Island, showing erythema of caudal peduncle. (b) Erythema of the ventral abdomen in a barramundi Lates calcarifer caught from the 7 Mile. (c) Cutaneous erosions, hemorrhage, and loss of scales in a barramundi L. calcarifer caught from the upper Boyne River. (d) Bull shark Carcharhinus leucas caught from the Boyne River showing region of cutaneous erosion (white arrow) with many Dermophthirius sp. (black arrows, inset). (e) Queenfish Scomberoides commersonianus caught $\sim 5 \mathrm{~km}$ south-east of the outer Gladstone Harbour dredge spoil disposal area. Patches of erythema on the ventral flanks and pectoral girdle (white arrow) associated with sea lice Lepeophtheirus spinifer (black arrows). (f) Corneal opacity and perforation in a barramundi L. calcarifer caught from the Boyne River

from Gladstone Harbour, but in only 3 of $23(13.0 \%)$ fish from the reference site. In fish infected with parasites, the number of parasites and the degree of severity of the associated host response was gener- ally greater in fish from Gladstone Harbour compared to fish from the reference site (Table 3). Common internal lesions included gastritis or enteritis associated with Coccidia-like organisms, observed in 
Table 3. Prevalence and severity of microscopic lesions attributable to parasites in finfish. 'Parasitic granulomas' includes those caused by protozoan and metazoan parasites. See Table 1 for species binomials/families, and a full list of species grouped as 'Other'

\begin{tabular}{|c|c|c|c|c|c|c|}
\hline Lesion & Species affected & $\begin{array}{l}\text { No. fish } \\
\text { examined by } \\
\text { histology }\end{array}$ & $\begin{array}{c}\text { No. } \\
\text { affected } \\
(\%)\end{array}$ & Mild & Moderate & Severe \\
\hline \multicolumn{7}{|l|}{ Gladstone Harbour } \\
\hline $\begin{array}{l}\text { Coccidial gastritis } \\
\text { or enteritis }\end{array}$ & $\begin{array}{c}\text { Barramundi; Requiem sharks; } \\
\text { Queenfish; Other }\end{array}$ & 27 & $15(55.6)$ & $4(26.7 \%)$ & $9(60 \%)$ & $2(13.3 \%)$ \\
\hline Parasitic granulomas & All species & 36 & $15(41.7)$ & $6(40 \%)$ & $5(33.3 \%)$ & $4(26.7 \%)$ \\
\hline $\begin{array}{l}\text { Sanguinocolid branchitis } \\
\text { or myocarditis }\end{array}$ & $\begin{array}{l}\text { Barramundi; } \\
\text { Queenfish }\end{array}$ & 16 & $9(56.2)$ & $6(66.7 \%)$ & $2(22.2 \%)$ & $1(11.1 \%)$ \\
\hline Lamellar henneguyosis & Barramundi & 9 & $6(66.7)$ & $3(50 \%)$ & $1(11.1 \%)$ & $2(22.2 \%)$ \\
\hline $\begin{array}{l}\text { Stanage Bay } \\
\text { Coccidial gastritis } \\
\text { or enteritis }\end{array}$ & $\begin{array}{c}\text { Barramundi; Requiem sharks; } \\
\text { Queenfish; Other }\end{array}$ & 13 & $7(53.8)$ & $6(85.7 \%)$ & $1(14.3 \%)$ & $0(0 \%)$ \\
\hline Parasitic granulomas & All species & 23 & $7(30.4)$ & $6(85.7 \%)$ & $1(14.3 \%)$ & $0(0 \%)$ \\
\hline $\begin{array}{l}\text { Sanguinocolid branchitis } \\
\text { or myocarditis }\end{array}$ & $\begin{array}{l}\text { Barramundi; } \\
\text { Queenfish }\end{array}$ & 7 & $1(14.3)$ & $0(0 \%)$ & $1(100 \%)$ & $0(0 \%)$ \\
\hline Lamellar henneguyosis & Barramundi & 6 & $3(50.0)$ & $2(66.7 \%)$ & $1(33.3 \%)$ & $0(0 \%)$ \\
\hline
\end{tabular}

requiem sharks and queenfish; visceral encysted cestode larvae, observed in mullet Mugil spp.; granulomas caused by microsporidia, myxozoa, or nematode larvae, observed in mullet; sanguinocolid branchitis and myocarditis, observed in queenfish and barramundi; enteric nematodiaisis, observed in queenfish and barramundi; lamellar epitheliocystis; and lamellar henneguyosis observed in barramundi.

Dermatitis was present in 22 of 32 (prevalence = $68.8 \%$ ) fish (where skin was available for histological examination) sampled from Gladstone Harbour
(Fig. 4). Dermatitis was either predominantly nonsuppurative (mononuclear) and perivascular $(\mathrm{n}=5)$, erosive $(\mathrm{n}=5)$, or ulcerative $(\mathrm{n}=12)$ in nature. Lesions were of variable chronicity, and species-specific lesion patterns were not evident. Ectoparasites were rarely associated with regions of erosion or ulceration in histological sections. Microbial infectious agents, such as bacteria or fungi, were not identified within lesions. Dermatitis was not identified in any of the 22 fish from the reference site where skin was histologically evaluated.
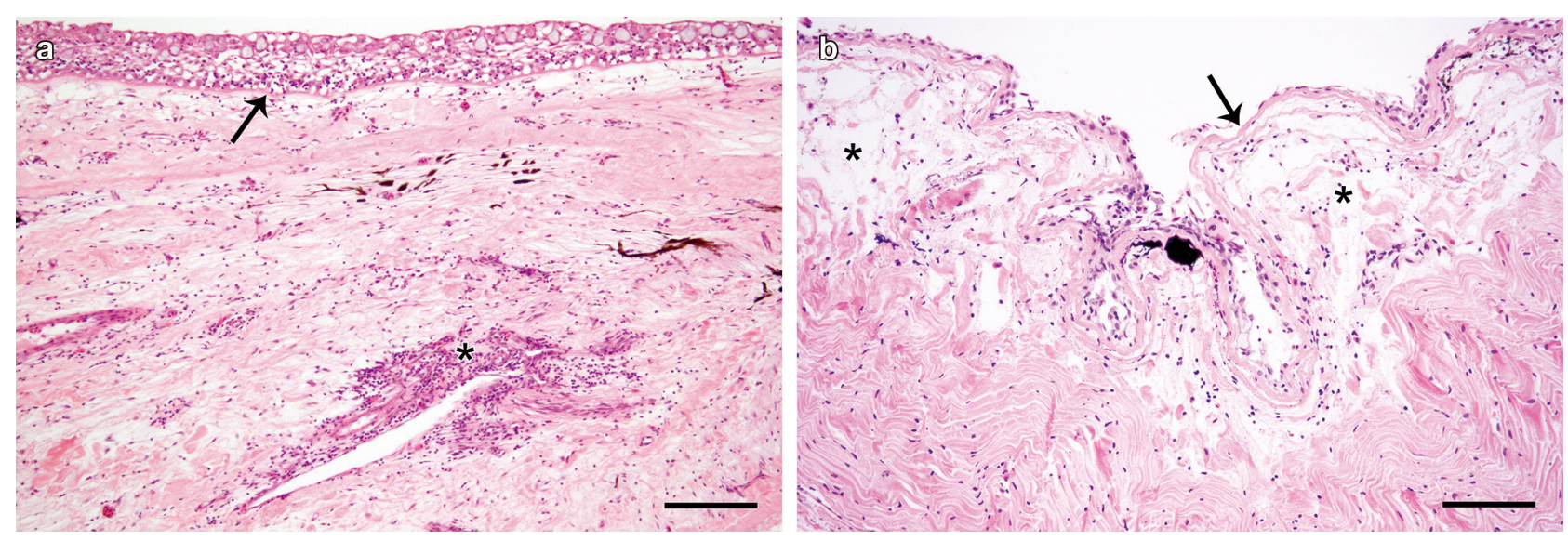

Fig. 4. (a) Erosive dermatitis in a barramundi L. calcarifer caught near the Boyne River in February 2012. The epidermis has segments of attenuation and reduced mucus cells. There is intercellular edema and mononuclear leukocyte infiltrate (arrow). The dermis is lacking scales, edematous, and has perivascular mononuclear leukocyte infiltrate (asterisk). (b) Ulcerative dermatitis in a catfish Arius sp. caught from the upper Boyne River in January 2012. There are segments of epidermal loss (arrow) sparsely marginated by few remaining epithelial cells. The dermis has severe edema (asterisks). H\&E. Scale bars $=100 \mu \mathrm{m}$ 
Table 4. Sample size, number of mud crabs Scylla serrata with lesions, mean (standard error) and median (interquartile range) lesion score (standard error), prevalence (95\% confidence intervals), relative risk (RR, $95 \%$ confidence intervals) and p-value for mud crab shell lesions by region in Gladstone Harbour, Australia

\begin{tabular}{|c|c|c|c|c|c|c|c|}
\hline \multirow[t]{2}{*}{ Region } & \multirow[t]{2}{*}{$\mathrm{n}$} & \multirow{2}{*}{$\begin{array}{l}\mathrm{n} \text { with } \\
\text { lesions }\end{array}$} & \multicolumn{2}{|c|}{ - Lesion score -} & \multirow{2}{*}{$\begin{array}{l}\text { Prevalence (\%) } \\
\text { Value }(95 \% \text { CI) }\end{array}$} & \multirow{2}{*}{$\begin{array}{c}\text { RR } \\
\text { Value }(95 \% \text { CI })\end{array}$} & \multirow[t]{2}{*}{$\mathrm{p}$} \\
\hline & & & Mean (SE) & Median (IQR) & & & \\
\hline Inner Harbour & 346 & 148 & $0.8(0.003)$ & 0 (1) & $43(38$ to 48$)$ & $6.4(2.1$ to 19.3$)$ & 0.0009 \\
\hline East Harbour & 122 & 75 & $1.0(0.01)$ & $1(1)$ & 61 (53 to 70$)$ & - & - \\
\hline Deception Bay/The Narrows & 70 & 35 & $1.1(0.02)$ & $0.5(1)$ & 50 (38 to 62$)$ & - & - \\
\hline West Harbour/Grahams Creek & 154 & 38 & $0.4(0.01)$ & $0(0)$ & 25 (18 to 31$)$ & - & - \\
\hline Outer Harbour & 297 & 91 & $0.7(0.004)$ & $0(1)$ & $31(25$ to 36$)$ & $4.6(1.5$ to 13.9$)$ & 0.0069 \\
\hline 7 Mile & 136 & 44 & $0.7(0.01)$ & $0(1)$ & $32(24$ to 40$)$ & - & - \\
\hline Colosseum & 161 & 47 & $0.6(0.01)$ & $0(1)$ & $29(22$ to 36$)$ & - & - \\
\hline Total Gladstone Harbour & 643 & 239 & $0.7(0.002)$ & 0 (1) & $37(33$ to 41$)$ & $4.9(1.9$ to 16.7$)$ & 0.0022 \\
\hline Stanage Bay & 153 & 21 & $0.3(0.01)$ & $0(0)$ & 14 (8 to 19$)$ & $2.1(0.6$ to 6.6$)$ & 0.2237 \\
\hline Out of Harbour Gladstone $^{a}$ & 45 & 3 & $0.1(0.006)$ & $0(0)$ & $7(0$ to 14$)$ & 1.0 & - \\
\hline
\end{tabular}

\section{Bacteriology}

No significant growth was obtained from 23 of 24 cultures after a total of $72 \mathrm{~h}$ of incubation at $25^{\circ} \mathrm{C}$. A light growth of Photobacterium damselae ssp. damselae was cultured from the kidney of a bull shark Carcharhinus leucas.

\section{Mud crabs}

A total of 643 mud crabs $S$. serrata were examined from 6 geographical regions within the Gladstone Harbour, 45 were examined from an Out of Harbour reference site in the Gladstone region, and 153 were examined from the Stanage Bay reference site (Fig. 1, Table 4). Grossly visible shell lesions (Andersen et al. 2000), referred to as 'rust spots' by fishermen, were common in crabs sampled from Gladstone Harbour (Fig. 5). These lesions were discrete areas $1 \mathrm{~mm}$ to $>40 \mathrm{~mm}$ in diameter of discoloured green-brown to orange outer shell, being sometimes bilaterally symmetrical. Some lesions showed shell ulceration and perforation. Among crabs sampled from the Gladstone region, the prevalence of shell lesions was significantly higher $(p=0.0022)$ in crabs from the Inner Harbour and Outer Harbour sampling sites (combined prevalence $=37 \%, 95 \%$ CI: 33 to $41 \%$ ) relative to crabs sampled from the Out of Harbour reference sites (prevalence $=7 \%, 95 \%$ CI: 0 to $14 \%$ ) (Table 4$)$. The prevalence of shell lesions was significantly higher ( $p=0.0018)$ in crabs from the Inner Harbour (prevalence $=43 \%, 95 \%$ CI: 38 to $48 \%$ ) compared to those of the Outer Harbour (prevalence $=31 \%, 95 \%$ CI: 25 to $26 \%$ ). Mud crabs sampled from the Inner Harbour were nearly 6.4 -fold more likely to have a
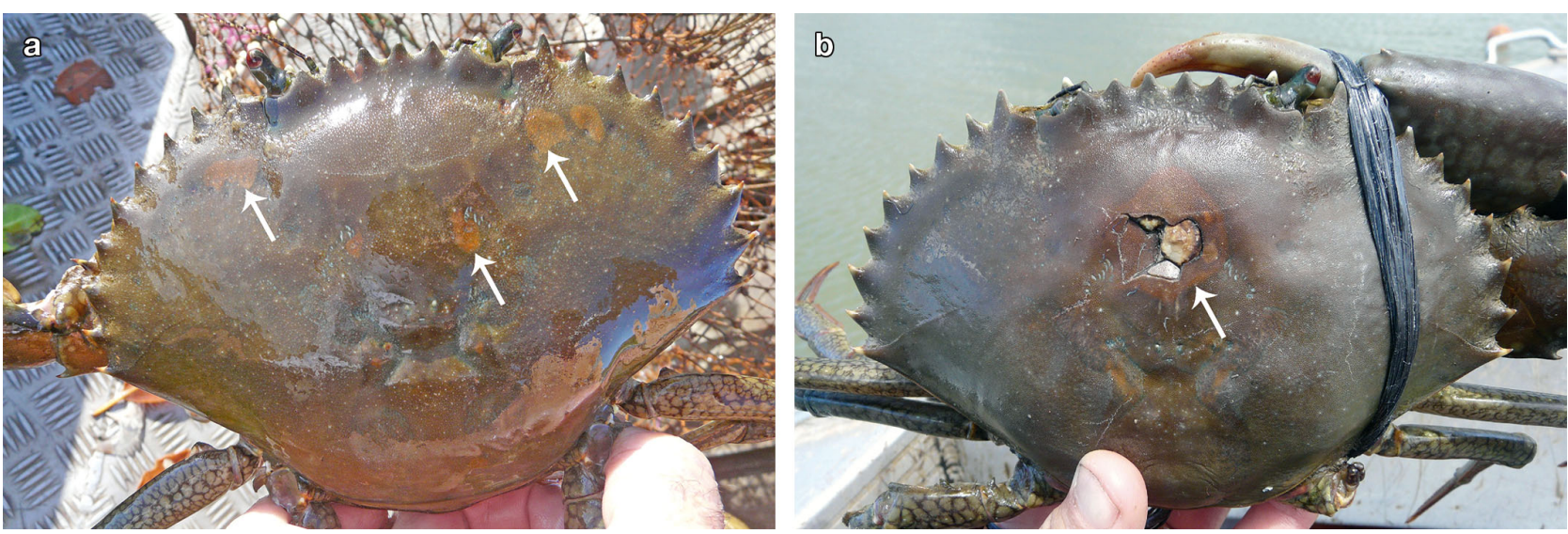

Fig. 5. Mud crabs Scylla serrata caught from The Narrows in February 2012 with (a) grade 2 'rust spots' (arrows) on the carapace and (b) grade 4 'rust spots' (arrow) which have ulcerated and perforate the carapace. Note bilateral symmetry of lesions 
shell lesion relative to those from the Out of Harbour reference sites (95\% CI: 2.1 to $19.3 \%$; $p=0.0009$ ). The prevalence of shell lesions in the crabs from Gladstone Harbour was also significantly higher than crabs from the Stanage Bay reference site (prevalence $=14 \%$, $95 \%$ CI: 8 to $19 \%$; p < 0.0001). There was a significant difference $(p=0.0004)$ in median lesion scores between mud crabs in Gladstone Harbour and those in the Out of Harbour reference sites.

The prevalence of histologically confirmed, degenerative to ulcerative shell disease was also higher in mud crabs sampled from Gladstone Harbour (9 of 15, prevalence $=60.0 \%$ ) relative to crabs from the Stanage Bay reference site (1 of 5, prevalence $=20 \%$ ). In addition, primary endocuticle degeneration was identified in 3 of the 9 crabs from Gladstone Harbour with shell disease, but was not observed in crabs from the Stanage Bay reference site. This lesion was characterized by formation of clefts beneath the exocuticle where the endocuticle was lost, vacuolated, and/or darkened (Fig. 6). Otherwise, observed shell lesions comprised erosions and ulcers extending through the epicuticle and exocuticle into the endocuticle, in some cases extending full thickness into the muscle beneath the endocuticle and accompanied by variable hemocyte infiltrate. Ulcers were colonized by mixed bacteria in 3 of $9(33.3 \%)$ crabs with ulcerative shell disease.

Apart from shell disease, the only other consistent histological finding observed in mud crabs was the differential presence of commensal organisms (including nematodes and ciliate protozoa) within sediment compacted between gill lamellae. This biofouling was more common in crabs from Gladstone Harbour (13 of 15 , prevalence $=86.7 \%$ ) relative to those sampled from the Stanage Bay reference site $(1$ of 5 , prevalence $=20.0 \%)$.

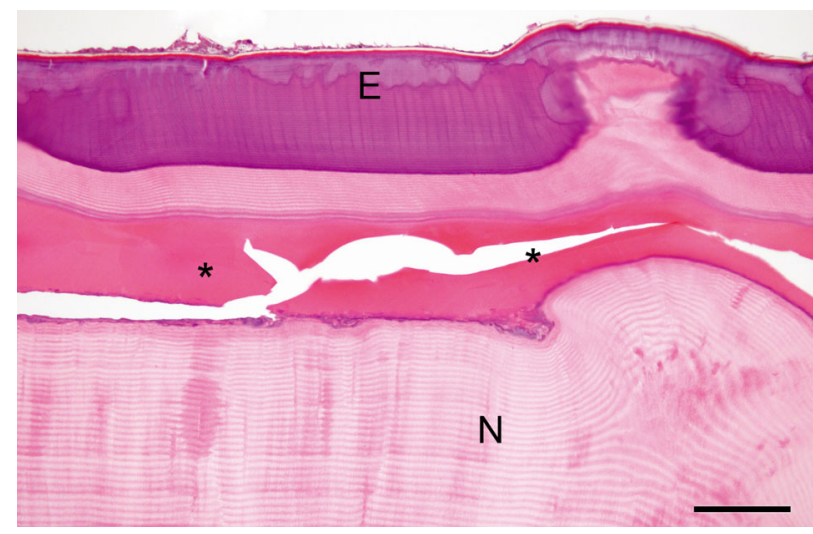

Fig. 6. Endocuticle degeneration in a mud crab Scylla serrata caught from The Narrows in February 2012. Note region of degeneration and clefting (asterisks) within the endocuticle (N). E denotes exocuticle. H\&E. Scale bar $=100 \mu \mathrm{m}$

\section{DISCUSSION}

Reports by fishers and the wider community of diseased fish in Gladstone Harbour peaked in September-October 2011 (Fig. 2, see Table S1 in the Supplement), coinciding with the height of the harbour development activity and the bund wall failure, nearly 6 mo after the harbour had returned to near full marine salinity. The exact extent to which disease prevalence increased in fishes of Gladstone Harbour during 2011 and 2012 is unknown due to the lack of baseline data for finfish health in Gladstone Harbour. Although reports of sick aquatic animals may have been inflated by heightened public awareness of the epidemic, the frequency with which diseases and dead fish were observed by the public was remarkable and regarded by the fishing and seafood industries to be highly unusual. Moreover, the present study found nearly one-quarter of finfish and over one-third of mud crabs Scylla serrata sampled from Gladstone Harbour had gross abnormalities in the early months of 2012, confirming high prevalence of disease.

The prevalence of diseased fish and crabs in Gladstone Harbour was significantly higher than at the reference site, indicating that causal mechanisms had a spatial linkage to Gladstone Harbour. For finfish, the higher prevalence values observed in Gladstone were especially influenced by barramundi Lates calcarifer, queenfish Scomberoides commersonianus, and requiem sharks (Family Carcharhinidae). The main abnormalities observed across fish species in Gladstone Harbour were dermatitis (predominantly ulcerative in nature) and high levels of ectoparasitism and inflammatory lesions associated with internal parasitism. An investigation by the Queensland government found similar abnormalities, only at lower prevalences than observed in our study (Department of Agriculture, Fisheries and Forestry 2013). This may reflect differences in methods for detecting and classifying abnormalities where a more extensive approach was undertaken by the present study.

Histopathology indicated that the cause of the skin lesions was not primarily of bacterial or fungal etiologies, in agreement with others (Department of Agriculture, Fisheries and Forestry 2013). Acute stress is widely recognized as a key factor for formation of ulcerative skin lesions in fish, and epidemics of skin ulcers in fish are considered indicators of aquatic environmental stress (Noga 2000). Glucocorticoid and catecholamine responses to primary stressors, including shifts in water quality, play a significant role in ulcer pathogenesis (Noga 2000). Moreover, certain environmental stressors, including hypoxia, $\mathrm{pH}$ ex- 
tremes, exposure to sediment (Redding et al. 1987, Mondon et al. 2001, Reid et al. 2003), and a wide range of pollutants, including heavy metals and ammonia (Noga 2000), may have a direct toxic effect to the integument. The statistical association of skin disease with ecto-parasitism in our study suggests that parasitic infection was an exacerbating factor in the pathogenesis of skin lesions for some of the finfish species examined in this study.

External and internal parasite infections were not only more prevalent within the study area but were also generally more severe in terms of degree of host inflammatory response, compared to observations in fish from the Stanage Bay reference site (Table 3). This is consistent with the high levels of parasitism observed in moribund and deceased green sea turtles Chelonia mydas from the Gladstone coastline, mid2011 (Flint et al. 2015). In the present study, the parasites associated with ulcerative dermatitis comprised monoxenous species that propagate when their respective host populations are stressed or immunosuppressed (Johnson \& Albright 1992). Epizootics of such parasites are unusual in wild fish, but increased intensity of infection with monoxenous parasites has been previously described in association with dredge spoil dumping (Hendrix 1985). Interestingly, the lesions associated with Dermophthirius sp. monogeneans and copepods of the genus Pandarus observed on requiem sharks (Family Carcharhinidae) in the present study are typically only associated with disease in captive aquarium sharks (Cheung et al. 1982, Thoney \& Hargis 1991). Similarly, the heavy sealice Lepeophtheirus spinifer infections and associated ulcerative dermatitis observed on queenfish $S$. commersonianus in the present study have not previously been described in wild queenfish but have been observed in high-intensity aquaculture of oyster cracker Trachinotus blochii (Cruz-Lacierda et al. 2011). The simultaneous presence of several marine fish species with conspicuous infections of different parasite species also suggests environmental stress, most likely involving the same water quality factors implicated in pathogenesis of the ulcerative skin disease.

The ocular disease observed in barramundi L. calcarifer in the study area was potentially a consequence of prior infection with Neobenedenia melleni, described in sampling undertaken in late August and early September 2011 by the Queensland Government (Department of Agriculture, Fisheries and Forestry 2013). However, no juvenile or adult Neobenedenia worms were recorded from the barramundi sampled in January and February 2012 in the present study, demonstrating the transient nature of the Neobene- denia infections in barramundi and confirming their lack of involvement in the wider disease epidemic that involved other marine species. However, in line with the observations of other parasite species, Neobenedia spp. have also only been reported causing disease in barramundi grown in high density for aquaculture in Australia (Deveney et al. 2001). Given that other fish species had similar ocular pathology, the possibility of primary conjunctival or corneal injury related to poor water quality is an alternative explanation (Hargis 1991).

In this study, mud crabs within Gladstone Harbour had higher prevalence of shell lesions (commonly referred to as 'rust spot disease') relative to crabs of Out of Harbour reference sites in the Gladstone region ( $p$ $=0.0022)$, and the Stanage Bay reference site $(\mathrm{p}<$ 0.0001). Furthermore, distance from the harbour development activity had a protective effect against shell lesions, where relative risk was lower in crabs from the Outer Harbour than the Inner Harbour. Moreover, our study's prevalence (37.6\%) was greater than historical levels of rust spot observed in Gladstone Harbour during previous dredging-associated shell disease epidemics in the late 1990s (21.7\%) (Andersen et al. 2000). A Fisheries Queensland survey detected much lower prevalence of mud crab shell disease $(5.3 \%)$, but Inner Harbour areas, shown to have the highest prevalence in our study, were not sampled (Department of Agriculture, Fisheries and Forestry 2013). Histological evaluation of the shell lesions of Gladstone Harbour crabs revealed endocuticle degeneration, consistent with that described by Andersen et al. (2000). This lesion is suspected to result from exposure to copper and zinc (Andersen et al. 2000, Andersen 2003). Elevated levels of dissolved copper and zinc were measured during compliance and government monitoring from September 2011 onwards at multiple sites around the bund wall, as well as areas of increased boat activity and dredging (Vision Environment 2011c,d, Department of Environment and Resource Management 2011).

Although neither ulcerative skin disease nor parasite infections and associated inflammatory responses can infer a specific causal mechanism, together their occurrence in one location over a wide range of host species is consistent with collective environmental stress. Given the temporal and spatial relationships with disease occurrence and water quality impacts, the harbour development is probably the most important factor contributing to an environmental change and therefore induction of stress during the epidemic. Dredging is highly disturbing to the aquatic environment, and previous much smaller scale dredg- 
ing operations in Gladstone indicated that the release of bioavailable metals impacted marine biota in the surrounding areas (Andersen et al. 2002). Through resuspension of the sea bed, contaminants present in the sediment, such as heavy metals and persistent organic pollutants, can be mobilized and become bioavailable to marine biota (Bonnet et al. 2000, Nayar et al. 2004, Cave et al. 2005, Knott et al. 2009, Burton \& Johnston 2010). The bioaccumulation of these contaminants can have detrimental effects on aquatic animal health (Rice \& White 1987, Zelikoff 1993, Mondon et al. 2000, Wilber \& Clarke 2001, Esslemont et al. 2004, Sturve et al. 2005, Hedge et al. 2009), and dredge-associated sediment and turbidity has also been linked to increased prevalence of disease in corals (Pollock et al. 2014). Finally, algal blooms can also form in association with dredging due to release of nutrients, such as nitrogen and phosphorus, and trace elements, including iron present in resuspended sediments and released pore water, and may further reduce dissolved oxygen levels and potentially cause direct injury to the host (Ahern et al. 2008).

The scale of Australia's largest dredging project (23 million cubic meters) was compounded by the fact that Gladstone Harbour appears particularly susceptible to resuspension impacts due to its distinctive hydrological, geological, and industrial history. Specifically of concern is the known presence of acid sulphate sediments and environmental accumulation of heavy metals, including copper, zinc, manganese, nickel, arsenic, tri-butyl tin, and aluminum (Apte et al. 2005, Jones et al. 2005, Andersen et al. 2006). Acid sulphate sediments that were disturbed during dredging and disposal activities can oxidize upon resuspension in water or in air on tidal banks and dredge barges, reducing $\mathrm{pH}$ and dissolved oxygen and further increasing the bioavailability of specific contaminants. The harbour was also exposed to increased resuspension risk due to its relatively slow (19 d) e-folding flushing rate (time for the total mass of material to decrease to one-third of its original mass) (Herzfeld et al. 2004).

While not directly addressed by our study, water quality observations recorded by others (in reports not released until after our investigation) support the hypothesis that the disease epidemic was related to the harbour development. First, disease was observed in areas corresponding to the distribution of resuspended sediments from dredging and disposal based on direct measurements of turbidity as well as interpretation of satellite images (Petus \& Devlin 2012). Second, numerous exceedances based on water quality guidelines and historical data (Aus- tralian and New Zealand Environment and Conservation Council 2000, Department of Environment and Heritage Protection 2009) for ammonia, turbidity and total suspended solids and a variety of sedimentassociated metals (including copper, zinc, aluminum, and iron) were documented in the harbour, near the bund wall area, through water and oyster testing, detected by engineering contractors for the port developers (BMT-WBM 2011a,b), project environmental monitors (Vision Environment 2011a,b,c,d,e, 2012a), an Australian government research institute (Angel et al. 2012), and the Queensland Government (Department of Environment and Resource Management 2012). When exceedances were commented upon in these reports, they were usually regarded as insignificant to fish health, as spurious results, or were ascribed to tides and winds despite such natural fluctuations being accounted for in the baseline data used to set trigger points in the first place. Barramundi L. calcarifer sampled from the inner harbour by Fisheries Queensland were reported to have high levels of iron ( 4000 mg kg-1 dry weight), cadmium ( $0.3 \mathrm{mg} \mathrm{kg}{ }^{-1}$ dry weight), zinc (135 $\mathrm{mg} \mathrm{kg}^{-1}$ dry weight), and arsenic ( 15 $\mathrm{mg} \mathrm{kg}^{-1}$ dry weight) in their livers compared to a reference site (Department of Agriculture, Fisheries and Forestry 2013). The report claimed heavy metals were not associated with external signs of poor fish health, but pathological effects may be subtle, and not all exposed fish would be expected to go on to develop skin ulcers or parasitism; thus, one cannot expect a strong association, and the lack of an association does not discount the role of metals in predisposing to illness. The report also indicated that hepatic metal concentrations were below those expected to have toxicological effects, but the levels at which hepatic accumulation of these metals is associated with toxicological effects have not been established for barramundi $L$. calcarifer. Seven river jewfish Johnius spp. sampled by Fisheries Queensland from the inner harbour were reported to have elevated aluminium levels in pooled gill samples (260 $\mathrm{mg} \mathrm{kg}^{-1}$ wet weight) (Department of Employment, Economic Development and Innovation 2012). Moreover, water testing at the peak of disease event (Vision Environment 2011c) revealed dissolved zinc at levels $\left(20 \mu \mathrm{g} \mathrm{l}^{-1}\right)$ known to impact immune function (Zelikoff 1993), dissolved copper at levels $\left(2 \mu \mathrm{g} \mathrm{l}^{-1}\right)$ known to impact olfactory sensation (Mirza et al. 2009, Tierney et al. 2010), and dissolved aluminium at levels $\left(30 \mu \mathrm{g} \mathrm{l}^{-1}\right.$ and up to $334 \mu \mathrm{g} \mathrm{l}^{-1}$; Angel et al. 2012) known to impact gill health and function in fishes (Teien et al. 2006, Kroglund et al. 2012, Thorstad et al. 2013). A range of 
metals, at levels well surpassing those reported for marine megafauna, as well as other contaminants were observed in the blood and tissues of Gladstone green turtles Chelonia mydas during mid-2011 and could be linked to the pathology observed in stranded or dead turtles (Gaus et al. 2012, Flint et al. 2015). Finally, algal blooms, involving species previously associated with fish kills and coinciding with deviations in water quality, were also documented during the fish disease epidemic (Vision Environment 2011c,d,e).

Throughout the disease epidemic, a view was advocated by the Queensland Government that the freshwater influx and the introduction of extra tonnage of barramundi $L$. calcarifer from Lake Awoonga, during the river flow event from December 2010 to April 2011, was the most likely underlying cause of the observed fish disease, rather than activities related to port development (Department of Agriculture, Fisheries and Forestry 2013). However, the 'flood theory' cannot explain the patterns of disease observed in our study, which was undertaken over a year after the start of the flooding event and found evidence of disease in a wide range of species other than barramundi, most of which were never present in Lake Awoonga. Water salinity monitoring documented freshwater inputs from rivers that temporarily lowered salinity throughout the inner and outer harbour. By the end of January 2011, the Western Basin Harbour salinity had already increased from the lows of 9-12 ppt in early January to 26 ppt ( 75\% of full-strength marine water) (Vision Environment 2011b). Further, fish which remained in Lake Awoonga did not experience a mortality event or demonstrate any signs of disease based on Queensland Government sampling (Department of Employment, Economic Development and Innovation 2012). The synchronous elevated mortalities and declines reported in dolphins, dugongs, and turtles also cannot be explained coherently by the 'flood theory' (Gaus et al. 2012, Cagnazzi et al. 2013, Cagnazzi 2013, Department of Environment and Heritage Protection 2011a,b,c). The levels of toxins detected in the blood of the turtles sampled in July 2011 indicated that the exposure was likely near the time of sampling, rather than several months prior (Gaus et al. 2012). Furthermore, similar multi-species disease epidemics were not observed at the reference site or in other regions of the Queensland coast that were also affected by river flow events in early 2011. Finally, flooding occurred at twice the height ( $8 \mathrm{~m} \mathrm{cf} .4 \mathrm{~m}$ ) over the Awoonga Dam wall in 2013; however, it did not coincide with a similar scale disease event in the Gladstone Harbour.
Moreover, perhaps because key documents were not made available to the public or scientists by project proponents at the time, the 'flood theory' does not consider obvious changes in turbidity, sedimentation, or the role of massive volumes (estimated at $3000 \mathrm{~kg}$ $\mathrm{min}^{-1}$ ) of dredge spoil leakage from the failed bund wall (BMT-WBM 2011a,b) and scouring of mud banks prior to and during the peak of the fish disease in September and October 2011 (Commonwealth of Australia 2014).

\section{CONCLUSION}

This study documents highly prevalent cutaneous and parasitic disease in multiple species of finfish and in mud crabs Scylla serrata, in association with a large-scale harbour development project. Estuarine environments in anthropogenically modified catchments are complex ecosystems where there are many possible contributing factors to any single problem. The unique hydrological, geological, and industrial history of Gladstone Harbour, the large scale of environmental modification due to the Western Basin harbour development, and the failure of the bund wall to contain dredged spoil within the reclaimed area are important factors contributing to the environmental stress that is indicated to have precipitated the disease epidemic observed in finfish and crabs during this study. This epidemic underscores the importance of establishing baseline animal health data, assessing animal health as part of environmental oversight programs, and using transparent oversight processes, fully independent from the managers, beneficiaries and contractors who may cause ecosystem impacts.

Acknowledgements. This study was funded by the Gladstone Fishing Research Fund, a public charity funded by Gladstone fishing and seafood industries and by private donations. Thanks to those who contributed to the Gladstone Fishing Research Fund to support this not-for-profit work. Our sincere appreciation goes to the commercial fishermen and the Gladstone Fish Market who assisted with sampling. The authors also thank those who contributed information on timing and location of diseased aquatic animals around Gladstone.

\section{LITERATURE CITED}

Ahern KS, Ahern CR, Udy JW (2008) In situ field experiment shows Lyngbya majuscula (cyanobacterium) growth stimulated by added iron, phosphorus and nitrogen. Harmful Algae 7:389-404 
Andersen LE (2003) A study into the epidemiology of mud crab (Scylla serrata) shell disease. MSc thesis, Central Queensland University, Gladstone

Andersen LE, Norton JH, Levy NH (2000) A new shell disease in the mud crab Scylla serrata from Port Curtis, Queensland (Australia). Dis Aquat Org 43:233-239

Andersen LE, Storey AW, Fox S (2002) Assessing the effects of harbour dredging using transplanted oysters as biomonitors. Centre for Environmental Management, Central Queensland University, Gladstone

Andersen L, Siu WHL, Ching EWK, Kwok CT and others (2006) Antioxidant enzymes as biomarkers of environmental stress in oysters in Port Curtis. Cooperative Research Centre for Coastal Zone, Estuary \& Waterway Management, Indooroopilly

Angel BM, Hales LT, Simpson SL, Apte SC, Chariton AA, Shearer DA, Jolley DF (2010) Spatial variability of cadmium, copper, manganese, nickel and zinc in the Port Curtis Estuary, Queensland, Australia. Mar Freshw Res 61:170-183

Angel BM, Jarolimek CV, King JJ, Simpson SL, Jung RF, Apte SC (2012) Metal concentration in the waters and sediments of Port Curtis, Queensland. CSIRO Wealth from Oceans Flagship, Tech Rep

Apte S, Duivenvoorden R, Johnson R, Jones M and others (2005) Contaminants in Port Curtis: screening level risk assessment. Tech Rep 25, Cooperative Research Centre for Coastal Zone, Estuary and Waterway Management, Indooroopilly

> Australian and New Zealand Environment and Conservation Council (2000) Paper no 4. Australian and New Zealand guidelines for fresh and marine water quality, Vol 2. Aquatic ecosystems - rationale and background information (Chap 8), National Water Quality Management Strategy, Australian Water Association, Artamon

> Australian Bureau of Meteorology (2014) Monthly rainfall, Calliope Station. Australian Bureau of Meteorology, Canberra

BMT WBM (2011a) Memo re: Gladstone Western Basin Dredge Monitoring - Preliminary Exceedance Investigation Findings. BMT WBM, Brisbane

BMT WBM (2011b) Port Curtis dredging and resuspension monitoring. BMT WBM, Brisbane

Bonnet C, Babut M, Ferard JF, Martel L, Garric J (2000) Assessing the potential toxicity of resuspended sediment. Environ Toxicol Chem 19:1290-1296

Burton GA, Johnston EL (2010) Assessing contaminated sediments in the context of multiple stressors. Environ Toxicol Chem 29:2625-2643

Cagnazzi D (2013) Review of coastal dolphins in central Queensland, particularly Port Curtis and Port Alma regions. Gladstone Port Corporation, Gladstone

> Cagnazzi D, Parra GJ, Westley S, Harrison PL (2013) At the heart of the industrial boom: Australian snubfin dolphins in the Capricorn Coast, Queensland, need urgent conservation action. PLOS ONE 8:e56729

> Cave RR, Andrews JE, Jickells T, Coombes EG (2005) A review of sediment contamination by trace metals in the Humber catchment and estuary, and the implications for future estuary water quality. Estuar Coast Shelf Sci 62: 547-557

- Cheung PJ, Nigrelli RF, Ruggieri GD, Cilia A (1982) Treatment of skin lesions in captive lemon sharks, Negaprion brevirostris (Poey), caused by monogeneans (Dermophthirius sp.). J Fish Dis 5:167-170

Commonwealth of Australia (2013) Independent review of the Port of Gladstone. Report on findings, commissioned by Minister for Sustainability, Environment, Water, Population and Communities, Hon Tony Burke. Australian Government Department of Environment and Energy, Canberra

Commonwealth of Australia (2014) Independent review of the bund wall at the Port of Gladstone. Report on findings, commissioned by Minister for the Environment, Hon Greg Hunt. Australian Government Department of Environment and Energy, Canberra

Cruz-Lacierda ER, Erazo-Pagador G, Yamamoto A, Nagasawa K (2011) Parasitic caligid copepods of farmed marine fishes in the Philippines. In: Bondad-Reantaso MG, Jones JB, Corsin F, Aoki T (eds) Diseases in Asian aquaculture VII. Fish Health Section, Asian Fisheries Society, Selangor, p 53-62

Davies JD, McCormack CV, Rasheed MA (2012) Port Curtis and Rodds Bay seagrass monitoring program. Biannual Western Basin \& annual long term monitoring. Report no. 13/08, TropWater and James Cook University, Townsville

Department of Agriculture, Fisheries and Forestry (DAFF) (2013) Gladstone Harbour Fish Health Investigation 2011-2012. Queensland Government, Brisbane

- Department of Employment, Economic Development and Innovation (DEEDI) (2012) Fish Health Sampling Report, Gladstone Harbour, as at 27 February 2012. Queensland Government, Brisbane

Department of Environment and Heritage Protection (2009) Queensland water quality guidelines. Queensland Government, Brisbane

$>$ Department of Environment and Heritage Protection (2011a) Marine Wildlife Stranding and Mortality Database Annual Reports 2011. I. Dugong. Queensland Government, Brisbane

Department of Environment and Heritage Protection (2011b) Marine Wildlife Stranding and Mortality Database Annual Reports 2011. III. Marine turtle. Queensland Government, Brisbane

Department of Environment and Heritage Protection (2011c) Marine Wildlife stranding and mortality database: annual reports 2008-2011. II. Cetaceans and pinnipeds. Queensland Government, Brisbane

Department of Environment and Resource Management (DERM) (2011) Water quality of Port Curtis and tributaries: supplementary report based on data collected in the week of $26^{\text {th }}$ September 2011. Queensland Government, Brisbane

Department of Environment and Resource Management (2012) Fourth update on the water quality of Port Curtis and tributaries including data collected in the week of 9 January 2012. Queensland Government, Brisbane

> Deveney MR, Chisholm LA, Whittington ID (2001) First published record of the pathogenic monogenean parasite Neobenedenia melleni (Capsalidae) from Australia. Dis Aquat Org 46:79-82

Esslemont G, Russell RA, Maher WA (2004) Coral record of harbour dredging: Townsville, Australia. J Mar Syst 52: 51-64

Flint M, Eden PA, Limpus CJ, Owen H, Gaus C, Mills PC (2015) Clinical and pathological findings in green turtles (Chelonia mydas) from Gladstone, Queensland: investigations of a stranding epidemic. EcoHealth 12: 298-309

Gaus C, Grant S, Ling Jin N, Goot K and others (2012) Investigation of contaminant levels in green turtles from Gladstone. ENTOX: National Research Centre for Environmental Toxicology, Brisbane 
Gladstone Fish Health Scientific Advisory Panel (2012) Final report. Available at www.ehp.qld.gov.au/gladstone/pdf/ gladstone-sap-report.pdf (accessed 5 May 2015)

Hargis WJ (1991) Disorders of the eye in finfish. Annu Rev Fish Dis 1:95-117

Hedge LH, Knott NA, Johnston EL (2009) Dredging related metal bioaccumulation in oysters. Mar Pollut Bull 58: 832-840

Hendrix SS (1985) Monogenetic trematodes from fishes of the New York Bight. In: Annual Midwest Conference of Parasitology Presentations. Ohio State University, Columbus, $\mathrm{OH}$

Herzfeld M, Parslow J, Andrewartha J, Sakov P, Wester IT (2004) Hydrodynamic modelling of the Port Curtis region. Project Tech Rep 7, CM2.11, CRC for Coastal Zone Estuary and Waterway Management, Indooroopilly

Jeremijenko A, Landos M (2014) Poster Abstracts: Harmful algal bloom in Gladstone harbour coincides with outbreak of toxic algal symptoms in 42 fishermen. Int Med J $44: 26-39$

Johnson SC, Albright LJ (1992) Effects of cortisol implants on the susceptibility and the histopathology of the responses of naïve coho salmon Oncorhynchus kisutch to experimental infection with Lepeophtheirus salmonis (Copepoda: Caligidae). Dis Aquat Org 14:195-205

Jones MA, Stauber J, Apte S, Simpson S, Vicente-Beckett V, Johnson R, Duivenvoorden L (2005) A risk assessment approach to contaminants in Port Curtis, Queensland, Australia. Mar Pollut Bull 51:448-458

> Knott NA, Aulbury JP, Brown TH, Johnston EL (2009) Contemporary ecological threats from historical pollution sources: impacts of large-scale resuspension of contaminated sediments on sessile invertebrate recruitment. J Appl Ecol 46:770-781

> Kroglund F, Finstad B, Pettersen K, Teien HC and others (2012) Recovery of Atlantic salmon smolts following aluminum exposure defined by changes in blood physiology and seawater tolerance. Aquaculture 362-363:232-240

Mirza RS, Green WW, Connor S, Weeks AC, Wood CM, Pyle GG (2009) Do you smell what I smell? Olfactory impairment in wild yellow perch from metal-contaminated waters. Ecotoxicol Environ Saf 72:677-683

Mondon JA, Duda S, Nowak BF (2000) Immune response of greenback flounder Rhombosolea tapirina after exposure to contaminated marine sediment and diet. Mar Environ Res 50:443-450

Mondon JA, Duda S, Nowak BF (2001) Histological, growth and 7-ethoxyresorufin 0-deethylase (EROD) activity responses of greenback flounder Rhombosolea tapirina to contaminated marine sediment and diet. Aquat Toxicol 54:231-247

> Nayar S, Goh BPL, Chou LM (2004) Environmental impact of heavy metals from dredged and resuspended sediments on phytoplankton and bacteria assessed in in situ mesocosms. Ecotoxicol Environ Saf 59:349-369

Noga EJ (2000) Skin ulcers in fish: Pfiesteria and other etiologies. Toxicol Pathol 28:807-823

Petus C, Devlin M (2012) Using satellite maps to document the extent of sediment plumes associated with dredging activity in Gladstone Port's western basin, Queensland. Catchment to Reef Research Group, James Cook University, final report 31 May 2012. ACTFR Research Publication $12 / 02$

Pollock FJ, Lamb JB, Field SN, Heron SF and others (2014) Sediment and turbidity associated with offshore dredging increase coral disease prevalence on nearby reefs.

\section{PLOS ONE 9:e102498}

R Core Team (2014) R: a language and environment for statistical computing. R Foundation for Statistical Computing, Vienna. www.r-project.org

Redding JM, Schreck CB, Everest FH (1987) Physiological effects on coho salmon and steelhead of exposure to suspended solids. Trans Am Fish Soc 116:737-744

Reid SM, Isaac G, Metikosh S, Evans J (2003) Physiological response of rainbow trout to sediment released during open-cut pipeline water crossing construction. Water Qual Res J Canada 38:473-481

Rice CP, White DS (1987) PCB availability assessment of river dredging using caged clams and fish. Environ Toxicol Chem 6:259-274

Sturve J, Berglund A, Balk L, Broeg K and others (2005) Effects of dredging in Goteborg Harbor, Sweden, assessed by biomarkers in eelpout (Zoarces viviparous). Environ Toxicol Chem 24:195-961

Teien HC, Kroglund F, Salbu B, Rosseland BO (2006) Gill reactivity of aluminium-species following liming. Sci Total Environ 358:206-220

Thoney DA, Hargis WJ (1991) Monogenea (Platyhelminthes) as hazards for fish in confinement. Annu Rev Fish Dis 1:133-153

Thorstad EB, Uglem I, Finstad B, Kroglund F and others (2013) Reduced marine survival of hatchery-reared Atlantic salmon post-smolts exposed to aluminium and moderate acidification in freshwater. Estuar Coast Shelf Sci 124:34-43

Tierney KB, Baldwin DH, Hara TJ, Ross PS, Scholz NL, Kennedy CJ (2010) Olfactory toxicity in fishes. Aquat Toxicol 96:2-26

Vicente-Beckett V, Shearer D, Munksgaard N, Hancock G, Morrison H (2006) Metal and polycyclic aromatic hydrocarbon contaminants in benthic sediments of Port Curtis. CRC for Coastal Zone, Estuary and Waterway Management, Indooroopilly

Vision Environment (2011a) BPPHA water quality and sedimentation data summary: Gladstone Ports Corporation (GPCL), Queensland Gas Corporation (QGC), December 2010. Vision Environment, Gladstone

Vision Environment (2011b) BPPHA water quality \& sedimentation data summary: Gladstone Ports Corporation (GPCL), Queensland Gas Corporation (QGC), March 2011. Vision Environment, Gladstone

Vision Environment (2011c) DMPA water quality monitoring: 15th to 30th September 2011. Vision Environment, Gladstone

Vision Environment (2011d) DMPA water quality monitoring: 1st-15th October 2011. Vision Environment, Gladstone

Vision Environment (2011e) WBDEM water quality logger summary: October 2011. Vision Environment, Gladstone

Vision Environment (2012a) WBDDP water quality: September and October 2011. Vision Environment, Gladstone and Asia-Pacific Applied Science Associates

Vision Environment (2012b) WBDEM water quality data summary, December 2011. Vision Environment, Gladstone

Whitman KA (2004) Finfish and shellfish; bacteriology manual, techniques and procedures. Iowa State Press, Ames, IA

Wilber DH, Clarke DG (2001) Biological effects of suspended sediments: a review of suspended sediment impacts on fish and shellfish with relation to dredging activities in estuaries. N Am J Fish Manage 21:855-875

Zelikoff JT (1993) Metal pollution-induced immunomodulation in fish. Annu Rev Fish Dis 3:305-325

Submitted: September 21, 2015; Accepted: April 28, 2016

Proofs received from author(s): September 15, 2016
Editorial responsibility: Thomas Braunbeck,

Heidelberg, Germany 